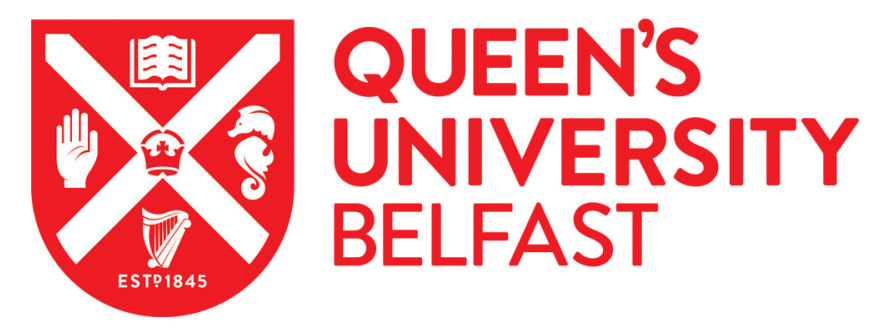

\title{
The role of sulfate-reducing prokaryotes in the coupling of element biogeochemical cycling
}

Bao, P., Li, G-X., Sun, G-X., Xu, Y-Y., Meharg, A. A., \& Zhu, Y-G. (2017). The role of sulfate-reducing prokaryotes in the coupling of element biogeochemical cycling. The Science of the total environment, 613-614, 398-408. https://doi.org/10.1016/j.scitotenv.2017.09.062

\section{Published in:}

The Science of the total environment

\section{Document Version:}

Peer reviewed version

\section{Queen's University Belfast - Research Portal:}

Link to publication record in Queen's University Belfast Research Portal

\section{Publisher rights}

Copyright 2017 Elsevier

This manuscript is distributed under a Creative Commons Attribution-NonCommercial-NoDerivs License

(https://creativecommons.org/licenses/by-nc-nd/4.0/), which permits distribution and reproduction for non-commercial purposes, provided the author and source are cited.

\section{General rights}

Copyright for the publications made accessible via the Queen's University Belfast Research Portal is retained by the author(s) and / or other copyright owners and it is a condition of accessing these publications that users recognise and abide by the legal requirements associated with these rights.

Take down policy

The Research Portal is Queen's institutional repository that provides access to Queen's research output. Every effort has been made to ensure that content in the Research Portal does not infringe any person's rights, or applicable UK laws. If you discover content in the Research Portal that you believe breaches copyright or violates any law, please contact openaccess@qub.ac.uk. 
1 Linking genes to biogeochemical cycling: lessons from arsenic

2 Yong-Guan Zhu, ${ }^{\dagger}, \ddagger, \#,{ }^{*}$ Xi-Mei Xue, ${ }^{\dagger,}{ }^{*}$ Andreas Kappler, ${ }^{\prime}$ Barry P Rosen, ${ }^{\S}$ Andrew

3 A Meharg ${ }^{\perp}$

$4 \dagger$ Key Laboratory of Urban Environment and Health, Institute of Urban Environment,

5 Chinese Academy of Sciences, Xiamen, China.

$6 \quad$ State Key Laboratory of Urban and Regional Ecology, Research Center for

7 Eco-Environmental Sciences, Chinese Academy of Sciences, Beijing, China

8 "Geomicrobiology, Center for Applied Geosciences, University of Tübingen,

9 Tübingen 72076, Germany

$10 \S$ Department of Cellular Biology and Pharmacology, Herbert Wertheim College of

11 Medicine, Florida International University, Miami, FL 33199, U.S.A.

$12 \perp$ Institute for Global Food Security, Queen's University Belfast, Belfast BT9 5HN,

13 United Kingdom

$15{ }^{\#}$ These authors contributed equally to the article.

16 *Address correspondence to Yong-Guan Zhu

17 Address: Institute of Urban Environment, Chinese Academy of Sciences, 1799 Jimei

18 Road, Xiamen 361021, China, Phone number: $+86(0) 592$ 6190997, Fax number:

19 +86(0)592 6190977, Email address: ygzhu@rcees.ac.cn 


\section{Abstract}

22 The biotransformation of arsenic is of particular relevance to biogeochemical

23 processes. Identification of the molecular details of microbial pathways of arsenic

24 biotransformation coupled with analyses of microbial communities by meta-omics

25 can provide insights into specific aspects of the complexities of the biogeochemical

26 arsenic cycle. Arsenic transformation couples to other biogeochemical cycles, and

27 to the fate of both nutrients and other toxic environmental contaminants. In some

28 cases, microbial metabolisms associated with redox of other elements (e.g. iron,

29 carbon and nitrogen) affect arsenic species, occurrence state, and bioavailability.

30 The arsenic biogeochemical cycle can be understood through the combination of

31 microbial geochemical activity analyses with biogeochemical models. In this

32 critical review we discuss how metagenomic-, metatranscriptomic-, metaproteomic-,

33 and metabolomic-based methods now and in the future will help to decipher

34 individual microbial arsenic transformation processes, their links to other

35 biogeochemical cycles, and allow us to use the metabolic capabilities of the

36 microbes involved for biotechnological purposes. Integrating biogeochemical

37 model and meta-omics data will offer novel insights into the evaluation and

38 prediction of arsenic biotransformation processes in the environment. It is believed

39 that lessons learnt from arsenic biogeochemistry can potentially be applied to other

40 biogeochemical processes. 


\section{Introduction}

Many biogeochemical cycles are inter-connected based on redox reactions of the transformations within each biogeochemical cycle. ${ }^{1}$ Any biogeochemical process, such as the cycling of a particular element, is likely to be mediated by more than one (micro)organism and is often linked to other biogeochemical processes. For example, the redox changes of arsenic are mediated by diverse arsenate (As(V))-reducing and arsenite (As(III))-oxidizing microbes. Arsenic biogeochemical cycling is often coupled to the cycling of iron, ${ }^{2}$ carbon ${ }^{3}$ and nitrogen, ${ }^{4}$ and to the dynamics of elements/ions associated with the arsenic redox cycle, such as sulfur. ${ }^{5}$ Coupling of biogeochemical cycles is receiving increasing attention in recent years since the study of coupled biogeochemical cycles will offer the scientific basis for some major environmental problems that we are facing today. ${ }^{6}$

The proteins catalyzing physiological processes in living organisms are influenced by geological, physical and chemical forces and therefore continuously evolve and redistribute between various chemical species involved in biogeochemical cycles. Genetic analysis is the key to understanding arsenic biogeochemical cycle. Once the genes associated with arsenic relevant reactions and the conditions that affect gene expression are understood, how organism metabolisms influence arsenic biogeochemical cycles will be predicted. This review focuses on an account of known functional genes involved in arsenic biotransformation and the effect of many other elements on arsenic biogeochemistry. Our article highlights the current state of meta-omics research in arsenic 
metabolizing microbes. It also attempts to discuss the integration of meta-omics information into biogeochemical models, with the aim of predicting elemental biogeochemistry in a given environment.

\section{Arsenic metabolism: from genes to biogeochemical processes}

Organisms have evolved various strategies to transform arsenic for detoxification or energy metabolism. An overview about the pathways for arsenic redox reactions and synthesis of novel organoarsenicals is presented in Figure 1. Each step of the reaction network is catalyzed by proteins encoded by genes. Genes involved in arsenic metabolism that have been identified are summarized in Table S1.

\subsection{The arsenic redox cycle}

The earliest microorganisms on Earth have evolved in an anoxic environment, where the relevant arsenic redox species was most probably the reduced As(III) rather than the oxidized $\mathrm{As}(\mathrm{V})$. The physiological activities of the earliest microorganisms were, therefore, largely driven by anaerobic metabolic processes, ${ }^{7}$ and As(III) bioavailability may have been a driving force for the evolution or acquisition of genes encoding proteins involved in anaerobic respiratory pathways. ${ }^{8}$ Microbes, such as Oscillatoria-like cyanobacteria that used As(III) as the sole photosynthetic electron donor to grow as a photoautotroph, ${ }^{9}$ or chemoautotrophic As(III)-oxidizers that could utilize As(III) as an electron donor and nitrate as an electron acceptor in energy-generating respiratory chains, ${ }^{10}$ probably evolved quite early. These microorganisms could cope with extreme growth conditions, such as high 
concentrations of As(III) or low oxygen, similar to those that existed in an primordial anoxic biosphere.

Since As(III) was probably the primary bioavailable arsenic species on the early anoxic Earth, it maybe an inevitable choice for organisms to utilize As(III) as an electron donor to produce energy. ${ }^{11} \mathrm{As}(\mathrm{III})$ oxidation is catalyzed by the enzyme As(III) oxidase, which contains two heterologous subunits, a large subunit $(\alpha)$ having molybdopterin and a $[3 \mathrm{Fe}-4 \mathrm{~S}]$ cluster (AioA) and a smaller subunit $(\beta)$ incorporating a Rieske-type [2Fe-2S] cluster (AioB). ${ }^{12}$ The cluster of aioA and aioB genes (aio operon) usually consists of aioS and aioR genes, encoding for a two-component signal transduction pair, AioS (sensor histidine kinase)/AioR (transcriptional regulator), which regulates expression of aio genes via recognizing As(III). ${ }^{13}$ The operon sometimes has an aioX gene that encodes an As(III)-binding protein involved in As(III)-based signaling and regulation of As(III) oxidation ${ }^{14}$, a cytC gene encoding a cytochrome $\mathrm{c}$ that is required for efficient As(III) oxidation in Ochrobactrum tritici SCII24, ${ }^{15}$ or a moeA gene that encodes the MoeA protein that synthesizes the molybdenum cofactor of AioAB oxidase. ${ }^{13}$ More recently, a new type of $\mathrm{As}(\mathrm{III})$ oxidase, ArxA, was identified in the chemolithoautotrophic Alkalilimnicola ehrlichii strain MLHE-1, which couples As(III) oxidation to $\mathrm{NO}_{3}{ }^{-}$ reduction. ${ }^{16}$ ArxA was found to catalyze As(III) oxidation coupled to photosynthesis in the purple-sulfur bacterium Ectothiorhodospira sp. strain PHS-1. ${ }^{17}$ Moreover, ArxA has greater homology to ArrA subunit than to AioA, and fills the phylogenetic gap between As(III) oxidases and As(V) reductases. ${ }^{16,17}$ 
photosynthetic microorganisms during the great oxidation event ca. 2.3-2.5 Ga, the majority of aqueous As(III) would have been oxidized to As(V). This presented both an opportunity and a challenge to the organisms of that time. The opportunity was that this new oxidized species could be used for energy generation by serving as a terminal electron acceptor. The challenge was that organisms were now exposed to a new environmental toxin, $\operatorname{As}(\mathrm{V})$, for which they had not developed any defenses.

To take advantage of the appearance of $\mathrm{As}(\mathrm{V})$ as a new potential terminal electron acceptor for the respiratory chain, dissimilatory As(V)-respiring prokaryotes (DARPs) evolved pathways that a new energy-generating respiratory chain utilizing the respiratory $\mathrm{As}(\mathrm{V})$ reductase, $\mathrm{Arr} A \mathrm{~B}$, that reduce the less toxic $\mathrm{As}(\mathrm{V})$ to the more consequence, early life had to evolve novel strategies for coping with new

124 (potentially toxic) arsenic species. As described in more detail below, nearly every 125 extant microbe has ArsB or Acr3 efflux permeases for As(III) detoxification, so it reasonable to assume that organisms that arose before the GOE already had an As(III) efflux system. When $\mathrm{As}(\mathrm{V})$ became the predominant soluble species, all cells had to do was to reduce $\mathrm{As}(\mathrm{V})$ to $\mathrm{As}(\mathrm{III})$, the substrate of $\mathrm{ArsB}$ or $\mathrm{Acr} 3$, and they would 
become resistant to $\mathrm{As}(\mathrm{V})$. A number of independently-evolved $\mathrm{As}(\mathrm{V})$ reductases arose in a variety of organisms using a small molecular mass protein $\mathrm{As}(\mathrm{V})$ reductases (one of several types of $\mathrm{ArsC}$ or $\mathrm{Acr} 2$ reductases). The ArsC system conferred by the ars operon is the most well studied mechanism of arsenic detoxification and resistance (for details see the previous review). ${ }^{20}$ These enzymes all use small molecule proteins such as glutaredoxin (Grx) or reduced glutathione (GSH) coupled to thioredoxin (Trx) as electron donor. The Acr2 reductases evolved from proteins that incorporated the phosphate binding loop of phosphorprotein tyrosine phosphatases related to the cell phosphatase CDC25. ${ }^{21}$ These phosphatase can be converted into $\mathrm{As}(\mathrm{V})$ reductases by just a few mutations, ${ }^{22}$ indicating a facile evolutionary path.

In addition to the Arr and $\mathrm{ArsC} \mathrm{As}(\mathrm{V})$ reductases, there are several other enzymes that have the potential to reduce $\mathrm{As}(\mathrm{V})$ to $\mathrm{As}(\mathrm{III})$. Most recently, a glutathione S-transferase B (GstB) was found to mediate an alternate pathway which conferred $\mathrm{As}(\mathrm{V})$ resistance to $E$. coli mutant cells lacking ars $C$ by directly reducing $\mathrm{As}(\mathrm{V})$ to $\mathrm{As}(\mathrm{III})$ with reduced GSH as the electron donor. ${ }^{23} \mathrm{~A}$ new As(V) reductase High Arsenic Content 1 (HAC1) ${ }^{24}$ and inositol transporters (AtINT2 and AtINT4) ${ }^{25}$ were identified to be required for $\mathrm{As}(\mathrm{V})$ reduction and $\mathrm{As}(\mathrm{III})$ loading into the phloem in Arabidopsis thaliana, respectively. There are other As(V) reductases related to the CDC25 phosphatases from rice, named as OsACR2.1 and OsACR2.2. 26 More and more arsenic reductases and trivalent arsenic-specific transporters 
identified show that arsenic reduction plays an important role in arsenic

151 biogeochemical cycling.

\subsection{The arsenic methylation cycle}

153 In addition to oxidation and reduction of inorganic arsenic species, pathways for 154 biotransformation of arsenic, including methylation and demethylation, 155 organoarsenical degradation, evolved in early organisms. Interest in arsenic 156 biomethylation began in 1800's with the observation that inorganic arsenic 157 compounds used as wallpaper pigments were converted into Gosio gas 158 (trimethylarsine) by fungi. More recent reports of methylated arsenical showed that 159 arsenic methylation was widespread in the environment and detected in bacteria, ${ }^{27}$ 160 cyanobacteria, ${ }^{28}$ algae, ${ }^{29}$ protozoan, ${ }^{30}$ et al. Arsenic methylation is always 161 considered as a common means to detoxify arsenic because the products are less 162 toxic pentavalent methylated arsenic species and the more toxic trivalent species are 163 only intermediates, and because the gaseous end-products escape from 164 cells/environments, leading to detoxification. The process is catalyzed by As(III) 165 S-adenosylmethionine (SAM) methyltransferases, designated as AS3MT in animals 166 and as ArsM in microorganisms. Expression of typical prokaryotic and archaeal

167 ars $M$ genes are regulated by ArsR, ${ }^{31}$ suggesting that arsenic methylation is a 168 detoxification pathway in the microbes. Expression of arsM in some cyanobacteria 169 appears to be constitutive, ${ }^{32}$ indicating that alternate detoxification pathways are used by microorganisms in which the expression of ars $M$ is not regulated. ${ }^{33}$ 

some time, ${ }^{34,}{ }^{35}$ while few molecular mechanisms for these reactions have been

173 demonstrated. Recently, a two-step pathway of MSMA reduction and demethylation 174 was elucidated. ${ }^{36}$ Although no reductases of pentavalent organoarsenicals have been 175 identified as yet, the enzyme, ArsI, which catalyzes demethylation of trivalent organoarsenicals, was identified and characterized from the environmental isolate 177 bacterium Bacillus sp. MD1 ${ }^{37}$ and from the cyanobacterium Nostoc sp. $7120 .{ }^{38}$ ArsI, 178 a non-heme iron-dependent dioxygenase with C-As lyase activity, cleaves the C-As 179 bond in MAs(III), trivalent roxarsone, and other trivalent aromatic arsenicals. 180 Putative ArsI orthologs were found only in bacterial species, suggesting that 181 alternate pathways of organoarsenical demethylation might exist in other organisms. 37

\subsection{The organoarsenical cycle}

The arsenic concentration in seawater is around 1 to $2 \mu \mathrm{g}$ per liter, mainly inorganic

185 arsenic that is usually transformed into complex organoarsenical compounds by 186 marine organisms. ${ }^{39}$ Arsenosugars, first identified in 1981,40 are commonly 187 detected water-soluble arsenic species present in marine algae; arsenobetaine is the 188 most abundant arsenical in the majority of marine animals. ${ }^{39}$ More complex 189 organoarsenicals have been identified with the improvement of analytical techniques 190 in recent years. Since the structure of an arsenosugar phospholipid (AsPL) from a 191 brown alga undaria pinnatifida was first identified, ${ }^{41}$ AsPL has been found in algae $192{ }^{42}$ and cyanobacteria. ${ }^{43}$ Arsenic-containing fatty acids (AsFA) that were first 
193 identified in cod liver oil ${ }^{44}$ have now been found in algae ${ }^{45}$ and various fish species.

46,47 AsHC that were first reported in capelin ${ }^{48}$ have been detected in fish ${ }^{46,47}$ and

195 algae. ${ }^{42}$ A new class of arsenolipids, trimethylarsenio fatty alcohols (TMAsFOH),

196 was recently reported in Capelin oil. ${ }^{49}$ Recently, two new groups of arsenolipids,

197 arsenic-containing phosphatidylcholines (AsPC) and arsenic-containing

198 phosphatidylethanolamine (AsPE) from herring caviar, were characterized. ${ }^{50}$ In total,

199 more than 20 arsenosugars and 70 arsenolipids have been identified, and most were

200 identified in marine organisms that live in low phosphate and high salt environments.

201 These organoarsenicals are not toxic for the marine plants and animals, but their

202 function in these marine organisms is not known. Phytoplankton can substitute

203 sulfur- and nitrogen-containing membrane lipids for membrane phospholipids, ${ }^{51}$

204 arsenolipids might be used in membranes in place of phospholipids due to the more

205 similarity of $\mathrm{As}(\mathrm{V})$, than sulfate and nitrate, to inorganic phosphate. Thus As(V)

206 could be used as a phosphate-sparing substitute in phosphate-limiting environments.

207 A recent study on Ectocarpus siliculosus that was found to produce more

208 arsenosugar phospholipids under low-phosphate than under normal phosphate

209 conditions ${ }^{52}$ supports this hypothesis.

210 However, these organoarsenicals may be toxic to organisms that cannot

211 biosynthesize them. In vitro toxicological characterization of three

212 arsenic-containing hydrocarbons showed that cytotoxicity of the arsenic-containing

213 hydrocarbons was comparable to that of As(III) for cultured human bladder and liver 
214 cells, ${ }^{53}$ and arsenolipids were metabolized by humans to DMA(V) and other small 215 molecular arsenic compounds, then excreted in the urine. ${ }^{54,55}$

216 Although several potential pathways have been proposed for the synthesis of 217 complex organoarsenicals, ${ }^{7}$ few genes involved in these biotransformation have 218 been identified. Even less is known about the degradation of these organoarsenicals, 219 and more studies are needed on this front.

\subsection{Arsenic efflux pathways}

221 The best way to deal with toxic arsenicals in cells is acquisition of an efficient efflux system. As(III) efflux systems have been intensively studied in both microbes and higher organisms. ${ }^{56,57} \mathrm{As}(\mathrm{III})$ efflux in most bacteria was mediated by ArsB in an energy-dependent process, driven in Staphylococcus aureus by the membrane potential ${ }^{58}$ and in E. coli by ATP hydrolysis that ArsA binds to ArsB to an ATP-driven arsenic-specific pump. ${ }^{59}$ In the legume symbiont S. meliloti, an aquaglyceroporin (AqpS), instead of ArsB, has been identified to extrude As(III)

228 from cells. ${ }^{60}$ Acr3 has been shown to be an As(III)-efflux transporter in both 229 bacteria and yeast, and provides a pathway for As(III) extrusion from cells. ${ }^{61}$ In fact, 230 genes for Acr3 are more wide-spread in bacteria and archaea than are arsB genes. 231 The cytosolic As(III)/glutathione complex sequestered into vacuoles by an 232 ABC-type transporter, Ycflp (yeast cadmium factor protein), is the second pathway 233 for As(III) detoxification in yeast Saccharomyces cerevisiae. ${ }^{62}$ 
genes that always go together, one encoding a typical glyceraldehyde-3-phosphate

237 dehydrogenase (GAPDH) and the second one, called arsJ, that encodes an

238 organoarsenical efflux permease (ArsJ). GAPDH uses As(V) and glyceraldehyde

239 3-phosphate to form the extremely unstable organoarsenical

240 1-arsenso-3-phosphoglycerate, which is extruded from cells by ArsJ and

241 immediately breaks down into $\mathrm{As}(\mathrm{V})$ and 3-phosphoglycerate. The net reaction is

242 effectively As(V) extrusion, and the coupled reaction confers As(V) resistance to

243 these microbes, the only known efflux pathway for As(V).

244 At the same time, the bacterial permease, ArsP, from Campylobacter jejuni,

245 was demonstrated to be an efflux system specific for trivalent organoarsenicals. ${ }^{64}$ It

246 is more selective for the ancient organoarsenical MAs(III) than for the recently

247 anthropogenically-developed antimicrobial aromatic arsenical growth promoters

248 such as trivalent roxarsone. This suggests that the earliest organisms may have had

249 the capability of methylating arsenic, and not to use arsenic methylation as arsenic

250 detoxification pathway instead of generating more toxic methylated arsenic

251 compounds and extruding them as antibiotics. ${ }^{65}$ Arsenic methylation slowly became

252 an arsenic detoxification pathway for organisms with increasing oxygen

253 concentration in the atmosphere. ${ }^{65}$

\section{3. Coupling of arsenic biogeochemical cycling to other elements}

256 Any biogeochemical process, such as the cycling of a particular element, is likely to

257 be mediated by more than one organism, and often linked to other fundamental 
biogeochemical processes. Arsenic transformation is often coupled to the cycling of

259 carbon, iron and nitrogen. ${ }^{66,2}$ The effect of Fe, $\mathrm{N}$, and natural organic matter (NOM)

260 turnover on arsenic biogeochemical cycling is summarized in Figure 2 based on

261 previous studies. 7, 67, 68, 69 The importance of these three biogeochemical cycles (Fe,

$262 \mathrm{~N}, \mathrm{C}$ ) for the environmental behavior of arsenic is described below.

263

264 transformation, dissolution and redox reactions. ${ }^{69,72,73}$ Previous studies from our

\subsection{The effects of iron on arsenic biogeochemical cycling}

The chemical speciation of arsenic in natural environments and arsenic mobility are strongly dependent on redox potential and $\mathrm{pH}$. Arsenic in solution occurs primarily as oxidized $\mathrm{As}(\mathrm{V})$ at oxidizing redox conditions $(500-200 \mathrm{mV})$, while arsenic is present mainly as $\mathrm{As}(\mathrm{III})$ at alkaline $\mathrm{pH}$ or upon reduction to $-200 \mathrm{mV}$. Arsenic is often adsorbed onto Fe(III) (oxyhydr)oxides in the form of $\mathrm{As}(\mathrm{V})$ under moderately reducing conditions $(0-100 \mathrm{mV}),{ }^{70} \mathrm{As}(\mathrm{III})$ appears to be more mobile. Below $\mathrm{pH}$ 5-6 the sorption of As(V) onto amorphous iron oxide and goethite is higher than that of $\mathrm{As}(\mathrm{III})$, at neutral $\mathrm{pH} \mathrm{As}(\mathrm{V})$ and $\mathrm{As}(\mathrm{III})$ sorption onto iron oxide is both relatively high, whereas above $\mathrm{pH} 7-8, \mathrm{As}(\mathrm{III})$ is more easily adsorbed to iron oxide than $\operatorname{As}(\mathrm{V}){ }^{71}$

Transformation of arsenic-bearing $\mathrm{Fe}$ mineral phases strongly affects the bioavailability of arsenic within soils and aquifers due to direct and indirect interactions between the arsenic and Fe cycles including mineral formation, 
279 induced artificially through adding ferrous iron in solution to paddy soils, has high 280 affinity for $\mathrm{As}(\mathrm{V})$, and reduced arsenic uptake by rice. ${ }^{74,75,76}$

281 Fe(III)-reducing bacteria modulate arsenic mobility in the rhizosphere.

282 Dissimilatory reduction of $\mathrm{Fe}(\mathrm{III})$ (oxyhydr)oxides to $\mathrm{Fe}(\mathrm{II})$ by dissimilatory 283 iron-reducing bacteria (DIRB) can result either in the release of As(V) from poorly 284 crystalline or more crystalline ferric minerals as well as from sorption sites within 285 sediments, ${ }^{77}$ or in the binding of arsenic to the formed Fe(II) minerals. ${ }^{78,79,80}$ DIRB 286 are commonly present in rice paddy soil, and mediate dissimilatory reduction of $287 \mathrm{Fe}(\mathrm{III})$ on the rice root-plaque. ${ }^{81} \mathrm{~A}$ study on the role of DIRB in arsenic release 288 under a range of biogeochemical regimes indicated that $\mathrm{Fe}(\mathrm{III})$ reduction was 289 stimulated by addition of acetate as a potential electron donor that resulted in a 290 marked increase in the number of DIRB, reduction of As(V) to As(III), and arsenic 291 release after $\mathrm{Fe}(\mathrm{III})$ reduction. ${ }^{82}$ If DARPs were used as Fe(III)-reducers, 292 Shewanella sp. ANA-3 ${ }^{83}$ or S. Barnesii ${ }^{84}$ could release both As(III) and Fe(II) from 293 ferrihydrite containing $\mathrm{As}(\mathrm{V})$ by reducing solid-phase $\mathrm{As}(\mathrm{V})$ and $\mathrm{Fe}(\mathrm{III})$. Eventually, 294 most of the ferrihydrite matrix was liberated as Fe(II) and As(III) if sufficient 295 organic electron donor was present. ${ }^{85}$

296 The release of arsenic by Fe(III) reduction (by DIRB) could be affected partly 297 by the metabolic activities of sulfate-reducing bacteria (SRB) that are integral parts 298 of microbial communities. SRB cause dramatic changes in Fe, sulfide and arsenic 299 species by generating hydrogen sulfide ${ }^{86}$ or elemental sulfur from sulfate. ${ }^{5}$ SRB 300 produce sulfide using $\mathrm{SO}_{4}{ }^{2-}$ and result in localized reprecipitation of released arsenic 
as poorly soluble sulfides such as arsenic trisulfide ${ }^{87}$ or Fe-As-sulfide. ${ }^{88}$ These transformations have the potential to significantly impact the fate of environmental arsenic.

In addition to $\mathrm{Fe}(\mathrm{III})$ reduction that has the potential to mobilize or immobilize arsenic depending on geochemical conditions that lead to the formation of either dissolved $\mathrm{Fe}^{2+}$ or $\mathrm{Fe}(\mathrm{II})$ minerals, the formation of $\mathrm{Fe}(\mathrm{III})$ minerals under Fe(II)-oxidizing conditions has the potential to significantly immobilize arsenic and thus to lower its bioavailability. ${ }^{89}, 90$ In particular for nitrate-reducing $\mathrm{Fe}(\mathrm{II})$-oxidizing bacteria it has been shown that they form poorly soluble $\mathrm{Fe}(\mathrm{III})$ minerals and efficiently co-precipitate arsenic (Figure 2). 89,90 Besides nitrate-dependent $\mathrm{Fe}(\mathrm{II})$ oxidation, also microaerophilic $\mathrm{Fe}(\mathrm{II})$ oxidation has the potential to influence arsenic mobility and could even be used in biotechnical applications for arsenic removal, e.g. in drinking water filters ${ }^{91}$ although it has been shown that in commercial drinking water filters the formation of iron biominerals by Fe(II)-oxidizing bacteria lowers arsenic removal from the water. ${ }^{92}$

\subsection{The effects of $\mathrm{N}$ on arsenic biogeochemical cycling}

Nitrate is an ecologically significant oxidant that can support microbial oxidation of As(III) in the absence of oxygen. The first evidence that microbes are capable of linking anoxic As(III) oxidation to denitrification came from a field study in anoxic lake water columns. ${ }^{4}$ The absence or presence of nitrate affected the redox state of arsenic. As(III) was present where nitrate was depleted, but $\mathrm{As}(\mathrm{V})$ was the dominant species during anoxic nitrate-rich periods. Subsequently, a nitrate-dependent As(III) 
oxidation bacterium A. ehrlichi strain MLHE-1 was found to be capable of coupling As(III) oxidation with partial denitrification of nitrate to nitrite. ${ }^{10,93}$ Two other anoxic chemolithoautotrophic strains, Azoarcus strain DAO1 and Sinorhizobium strain DAO10, were able to oxidize $\mathrm{As}(\mathrm{III})$ and fix $\mathrm{CO}_{2}$ via complete denitrification

327 of nitrate to dinitrogen gas. ${ }^{94}$ Biological nitrate-dependent As(III) oxidation is widespread in the environment, and potentially plays a significant role in arsenic biogeochemical cycling. ${ }^{95}$

As mentioned above, nitrate also influences the bioavailability and mobility of arsenic indirectly by linking nitrate reduction to Fe(II) oxidation. Previous studies

332 showed tight coupling between $\mathrm{N}, \mathrm{Fe}$, and arsenic in paddy soil. ${ }^{66}$ Addition of nitrate reduced arsenic uptake by rice probably because i) the nitrate 334 inhibited/reduced $\mathrm{Fe}(\mathrm{III})$ reduction leading to less arsenic mobilization and ii) nitrate-dependent $\mathrm{Fe}(\mathrm{II})$-oxidizing bacteria stimulated $\mathrm{Fe}(\mathrm{II})$ oxidation, which led to arsenic co-precipitation with Fe(III) minerals in soil. Nitrate strongly affects arsenic cycling under anoxic conditions in nitrate-rich Upper Mystic Lake by microbially 338 catalyzing $\mathrm{As}(\mathrm{III})$ to more particle-reactive $\mathrm{As}(\mathrm{V})$ and oxidizing $\mathrm{Fe}(\mathrm{II})$ to 339 arsenic-sorbing particulate ferric oxides. ${ }^{4}$ Microbial nitrate-dependent $\mathrm{Fe}(\mathrm{II})$ 340 oxidation in groundwater, ${ }^{96}$ freshwater sediments ${ }^{97}$ and marine sediments ${ }^{98}$ has the 341 potential to contribute to the reduction of arsenic mobility in various ecosystems.

\subsection{The effects of organic matter on arsenic biogeochemical cycling}

343 Organic matter affects the fate of arsenic by competitive adsorption and redox reactions, 99, 100, 101 and formation of arsenic-bearing organic-metal-complexes and 
mineral colloids. ${ }^{102,103} \mathrm{NOM}$ is considered to be an efficient geochemical trap for arsenic both under oxic and reducing conditions. Whereas $\mathrm{As}(\mathrm{V})$ is immobilized by

347 binding to protonated amino groups of $\mathrm{NOM}^{3}$ or a nucleophile substitution reaction

348 between $\mathrm{As}(\mathrm{V})$ and phenolic $\mathrm{OH}$ groups of NOM, ${ }^{104} \mathrm{As}(\mathrm{III})$ is associated with

349 NOM via phenolic $\mathrm{OH}$ or carboxyl groups of NOM by H-bonding, hydrophobic $350 \mathrm{As}(\mathrm{III})-\mathrm{NOM}$ interactions, ${ }^{104}$ or via ternary $\mathrm{As}(\mathrm{III})-\mathrm{Fe}(\mathrm{III})-\mathrm{NOM}$ complexes that 351 form bridges between Fe(III), arsenic oxyanions and the functional entities of NOM. 352105,106 In contrast, under sulfate-reducing conditions, the formation of a 353 trigonal-pyramidal complex between As(III) and sulfhydryl groups of NOM could 354 potentially be a sequestration mechanism for arsenic. ${ }^{107}$

355 Organic matter could also change the fate of arsenic by influencing microbial 356 communities. NOM is thought to drive the reductive dissolution of $\mathrm{Fe}$ (III) 357 (oxyhydr)oxides, thereby causing redox transformations of $\mathrm{As}(\mathrm{V})$ to $\mathrm{As}(\mathrm{III})$ and 358 facilitate arsenic release. ${ }^{107}$ In addition to the reductive dissolution of 359 arsenic-bearing Fe(III) (oxyhydr)oxide phases, our studies revealed that addition of 360 organic matter to paddy soil significantly increased arsenic methylation and 361 volatilization. ${ }^{108}$ Application of rice straw into soil increased arsenic accumulation 362 in rice by influencing microbial processes involved in arsenic redox. ${ }^{109}$

363 Apart from iron oxides and organic materials, silicon significantly decreased 364 As(III) concentration, but increased the concentration of DMAs in both the 365 vegetative and reproductive tissues of rice. ${ }^{110}$ In brief, in addition to biological 366 transformations, other inorganic elements, compounds/minerals and 

arsenic with other elements makes it necessary to consider genes involved in cycling of other elements, such as $\mathrm{Fe}, \mathrm{N}, \mathrm{S}$, and carbon when studying the arsenic biogeochemical cycling.

\section{Understanding biogeochemical arsenic cycling by}

\section{application of "omics" methods and integrated modeling}

Microbes are ubiquitous in nature and so govern critical processes of arsenic biotransformation and influence arsenic redox speciation and bioavailability in soils,

376 sediments and bodies of water. ${ }^{111}$ Currently, attention is being paid to functional 377 groups and functional genes in the environment, and their linkage with biogeochemical processes. Genes associated with arsenic biotransformation are 379 widely distributed in paddy soils, and the variation in gene distribution and abundances were driven by soil properties, such as $\mathrm{pH}$, total $\mathrm{C}$ and $\mathrm{N}$ content, $\mathrm{Fe}$, etc. 112, 113 Microbes involved in arsenic transformation were found to be ubiquitously distributed in paddy soils, resulting in various concentrations and percentage of 383 inorganic and methylated arsenic species among different rice plants. ${ }^{114,115,116}$ Since

384 higher plants appear not to methylate arsenic, ${ }^{117}$ microbial mediated methylation is 385 probably the primary source of methylated arsenic in plants, which is expected to 386 occur in soil prior to plant uptake. characterized and easily quantified in laboratory studies with pure cultures of 
microorganisms, the speciation, fate and biogeochemical transformation processes of arsenic in the environment are much more complex to determine due to the fact that

391 arsenic biogeochemical cycling is driven by various arsenic metabolism genes and genes involved in other element cycles or related to arsenic bioavailability. It is therefore necessary to apply more systematic and more comprehensive approaches, such as metagenomics, metatranscriptomics, metaproteomics, and metabolomics to understand the interactions between environmental microbes, their geochemical surrounding, and neighboring organisms by analyzing DNA, RNA, proteins, and metabolites extracted directly from environmental samples.

\subsection{Metagenomics}

Metagenomics provides an inestimable window into the microbial world by characterizing microorganisms involved in difficult-to-elucidate but important biochemical pathways, as the overwhelming majority of microbes in the environment can not be cultured in the laboratory. Chauhan et al constructed a metagenomic library, identified two arsenic-resistant bacteria and one novel As(V) resistance gene $(\operatorname{ars} N)$ which encodes a protein similar to acetyltransferases. ${ }^{118}$ Metagenomics was also used to unravel the correlations between the microbes and arsenic transformation in different niches. 119, 120, 121 Although metagenomics 407 provides us the taxonomic and functional profiles of a microbial community but does 408 not tell us the expression levels of the genes nor their physiological activity. ${ }^{122}$ 409 Therefore, metatranscriptomics is needed to delineate the active functional genes and communities. 


\subsection{Metatranscriptomics}

Metatranscriptomics offers novel insights into the expression of functional genes and microbial activities of complex microbial communities at a specific moment or under specific environmental conditions by sequencing the total mRNAs extracted from natural microbial communities. ${ }^{123}$ Functional metatranscriptomics has potential for isolation and characterization of novel genes involved in heavy metal transformation. ${ }^{124}$ Metatranscriptomics enhances our understanding of microbial responses to their environment ${ }^{125}$ and the functional profile of a microbial community. ${ }^{126}$ Recently, a transcriptomics meta-analysis was used to unravel the effect of As(III) on the symbiotic interaction between Medicago-Ensifer ${ }^{127}$ and adaptive responses of bacteria to arsenic exposure. ${ }^{128}$ The metatranscriptomic approach will be useful to study how microbes regulate their genes to adapt to the changes in environmental conditions, particularly arsenic concentrations.

\subsection{Metaproteomics and metabolomics}

Metaproteomics and metabolomics are the comprehensive methods by which proteins produced by microbes and metabolites released by microorganisms into the environment are characterized and quantified using a combination of liquid or gas chromatography-based separations and mass spectrometry-based identification techniques. ${ }^{129,130}$ The study of microbial proteome and metabolome can provide valuable information about the function of microbial communities and the interactions of the microbial communities with the environment. ${ }^{131},{ }^{132}$ When the diversity of arsenic-adapted prokaryotic communities in mildly arsenic-contaminated 
433 453 and responds to environmental parameters. ${ }^{136}$ Taken together, meta-omic

sediments was analyzed using meta-proteomic and 16S rDNA amplification, the results indicated that the data sizes provided by metaproteomics are less than those provided by metagenomics and metatranscriptomics. ${ }^{133}$ So far, metabolomics has been used mainly to analyze low molecular mass metabolites within a tissue, biofluid, a cell or cell compartment of an organism including plants, animals, bacteria, and human exposed to environmental stressor. ${ }^{132}$ High-throughput metabolomics has been applied to the analysis of metabolites in the liver of mice when co-exposed to high fat and cholesterol diets and arsenic-contaminated drinking water. ${ }^{134}$ However, application of metaproteomic and metabolomic techniques to real environment is limited due to difficulties with amplification and the low quantities of extractable proteins and metabolites because of the interferences with many components present in complex environmental systems, such as soil. ${ }^{132,135}$

\subsection{Integrating meta-omic techniques}

From the above, meta-omics are key techniques in elucidating the dynamic and complex interactions between microbial communities and the environment. Integrating multiple meta-omic datasets will provide a complete exhibition from genes to biogeochemical cycles. Metatranscriptomic and metagenomic techniques were combined to detect large numbers of novel genes from complex marine microbial communities. ${ }^{126}$ Datasets of meta-genomics were integrated with metabolomics to reveal how a microbial community interacts with the environment

454 technologies offer an unprecedented opportunity to elucidate the functions of 
470 information on functional genes cannot predict the status of arsenic in the

471 environment. In addition, arsenic biogeochemistry is also controlled by other 472 environmental factors. The information of field/in situ characterization of functional 473 genes/functional microbial communities and biogeochemical fluxes should be 474 integrated into biogeochemical models to complete the transition from lab to the 475 field, from biochemistry to biogeochemistry, and from genes-genomics to microbial 476

microbes that are not readily cultured under normal laboratory conditions in biogeochemical cycles.

Recently, "Arsenomics" was termed as an approach to focusing on the analysis of alterations in transcriptome, proteome and metabolome occurring in microbes exposed to arsenic. ${ }^{137,138}$ With the application of meta-omics to environmental science, we believe that Arsenomics will evolve to include the analysis of metagenomic, metatranscriptomic, metaproteomic, and metabolomic changes in microbial communities from the real environment where they are exposed to arsenic.

\subsection{Integrating environmental meta-omics into biogeochemical models for} arsenic

Microbes are ubiquitous in diverse environmental niches including soil, oceans, sediments, freshwater environments, and inside the body of animals or plants, and exert great influence on biogeochemical cycles in these habitats. Characterization of genes involved in arsenic biotransformation and application of multiple meta-omics in environment analysis will lead to insights into the microbial world, as limited environmental factors. The information of field/in situ characterization of functional communities. This integration will help to predict the dynamics of arsenic in the 
environment, and to improve the effectiveness of mitigation technologies. Many strategies have been developed to model low complexity environments. For example, recent work integrating environmental genomics and qPCR in biogeochemical models explored the nexus between microbial community and geochemisty in the Arabian Sea oxygen minimum zone. ${ }^{139}$ Recently, metabolic processes coupling carbon, nitrogen, and sulfur transformations in the Saanich Inlet oxygen-starved zone were integrated using a biogeochemical model that integrates multi-omic information and geochemistry. ${ }^{140}$ These studies indicated that such integrated modeling approaches can provide a novel insight into microbial metabolic networks in water bodies, and pave a road for prediction of elemental cycling.

\section{Perspectives}

In summary, as arsenic biotransformations are catalyzed by a suite of enzymes from diverse environmental organisms, and these are coupled to biogeochemical cycles of other elements such as Fe, S, and N. As more and more genomes are being sequenced, more genes directly or indirectly involved in arsenic metabolism will be discovered and characterized. With the development of new technologies, we anticipate rapid advances in analytical chemistry, microbiology and genomics that will improve our understanding of how microbial metabolic pathways contribute to and govern complex environmental processes. In the future, integrating meta-omic datasets into biogeochemical models will improve the ability of prediction and offer a deeper insight into arsenic biogeochemical processes in diverse niches. 
499

500 501 and the environment using additional meta-omics approaches at different

502

503

504

505

506

507

508

509

510

511

512

513

514

515

516

517

518

519

520

521

522

In future studies, it will be necessary to perform the phylogenetic analyses of the genes involved in arsenic metabolism and analyze the interaction between organisms spatio-temporal scales. Geochemical analyses in combination with genetic analyses will provide insights into the specific roles of the complex biochemical pathways in the global arsenic biogeochemical cycle. More importantly, integrating modeling approaches linking arsenic biogeochemical cycle with meta-omics data should be developed to predict the dynamic of arsenic species in water, sediments and soils and provide our society and authorities with the tools necessary for limiting arsenic pollution, improving remediation and providing safe drinking water and food.

\section{Acknowledgments}

Our research was supported by the National Natural Science Foundation of China (41571130063, 41430858, and 21507125) and the International Science \& technology Cooperation Program of China (2011DFB91710). BPR was supported by

NIH grants GM55425 and ES023779.

\section{Reference}

(1) Bashkin V N. Modern biogeochemistry; Springer Science \& Business Media, 2002.

(2) Oremland, R. S.; Stolz, J. F. The ecology of arsenic. Science 2003, 300, 939-944; DOI

10.1126/science. 1081903

(3) Thanabalasingam, P.; Pickering, W. F. Arsenic sorption by humic acids. Environ. Pollut. (Series B) 1986, 12 (3), 233-246; DOI 10.1016/0143-148X(86)90012-1

(4) Senn, D. B.; Hemond, H. F. Nitrate controls on iron and arsenic in an urban lake. Science 2002, 
296, 2373-2376; DOI 10.1126/science.1072402

(5) Saalfield, S.; Bostick, B. Changes in iron, sulfur, and arsenic speciation associated with bacterial sulfate reduction in ferrihydrate-rich systems. Environ. Sci. Technol. 2009, 43, 8787-8793; DOI 10.1021/es901651k

(6) Finzi, A. C.; Cole, J. J.; Doney, S. C.; Holland, E. A.; Jackson, R. B. Research frontiers in the analysis of coupled biogeochemical cycles. Front Ecol Env. 2011, 9 (1), 74-80; DOI $10.1890 / 100137$

(7) Zhu, Y.-G.; Yoshinaga, M.; Zhao, F.-J.; Rosen, B. P. Earth Abides Arsenic Biotransformations. Annu. Rev. Earth Planet. Sci. 2014, 42 (1), 443-467; DOI 10.1146/annurev-earth-060313-054942

(8) Oremland, R. S.; Saltikov, C. W.; Wolfe-Simon, F.; Stolz, J. F. Arsenic in the Evolution of Earth and Extraterrestrial Ecosystems. Geomicrobiol. J. 2009, 26 (V), 522-536; DOI 10.1080/01490450903102525

(9) Kulp, T. R.; Hoeft, S. E.; Asao, M.; Madigan, M. T.; Hollibaugh, J. T.; Fisher, J. C.; Stolz, J. F.; Culbertson, C. W.; Miller, L. G.; Oremland, R. S. Arsenic(III) fuels anoxygenic photosynthesis in hot spring biofilms from Mono Lake, California. Science 2008, 321 (5891), 967-970; DOI 10.1126/science.1160799

(10) Oremland, R. S.; Hoeft, S. E.; Santini, J. M.; Bano, N.; Hollibaugh, R. a; Hollibaugh, J. T. Anaerobic Oxidation of Arsenite in Mono Lake Water and by a Facultative, Arsenite-Oxidizing Chemoautotroph, Strain MLHE-1. Appl Env. Microbiol 2002, 68 (10), 4795-4802; DOI 10.1128/AEM.68.10.4795

(11) Kulp, T. R. Arsenic and primordial life. Nat. Geosci. 2014, 7 (11), 785-786; DOI 10.1038/ngeo2275

(12) Basu, P.; Stolz, J. F.; Oremland, R. S. Microbial Arsenic Metabolism: New Twists on an Old Poison. Microbe Mag. 2010, 5 (2), 53-59; DOI 10.1128/microbe.5.53.1

(13) Sardiwal, S.; Santini, J. M.; Osborne, T. H.; Djordjevic, S. Characterization of a two-component signal transduction system that controls arsenite oxidation in the chemolithoautotroph NT-26. FEMS Microbiol. Lett. 2010, 313 (1), 20-28; DOI 10.1111/j.1574-6968.2010.02121.x

(14) Liu, G.; Liu, M.; Kim, E. H.; Maaty, W. S.; Bothner, B.; Lei, B.; Rensing, C.; Wang, G.; McDermott, T. R. A periplasmic arsenite-binding protein involved in regulating arsenite oxidation. Environ. Microbiol. 2012, 14 (7), 1624-1634; DOI 10.1111/j.1462-2920.2011.02672.x

(15) Branco, R.; Francisco, R.; Chung, A. P.; Morais, P. V. Identification of an aox system that requires cytochrome $\mathrm{c}$ in the highly arsenic-resistant bacterium Ochrobactrum tritici SCII24. Appl. Environ. Microbiol. 2009, 75 (15), 5141-5147; DOI 10.1128/AEM.02798-08

(16) Zargar, K.; Hoeft, S.; Oremland, R.; Saltikov, C. W. Identification of a novel arsenite oxidase gene, arxA, in the haloalkaliphilic, arsenite-oxidizing bacterium Alkalilimnicola ehrlichii strain MLHE-1. J. Bacteriol. 2010, 192 (14), 3755-3762; DOI 10.1128/JB.00244-10

(17) Zargar, K.; Conrad, A.; Bernick, D. L.; Lowe, T. M.; Stolc, V.; Hoeft, S.; Oremland, R. S.; Stolz, J.; Saltikov, C. W. ArxA, a new clade of arsenite oxidase within the DMSO reductase family of molybdenum oxidoreductases. Environ. Microbiol. 2012, 14 (7), 1635-1645; DOI 10.1111/j.1462-2920.2012.02722.x

(18) Zobrist, J.; Dowdle, P. R.; Davis, J. A.; Oremland, R. S. Mobilization of arsenite by 
dissimilatory reduction of adsorbed arsenate. Environ. Sci. Technol. 2000, 34 (22), 4747-4753; DOI 10.1021/es001068h

569

570

571

572

573

574

575

576

577

578

579

580

581

582

583

584

585

586

587

588

589

590

591

592

593

594

595

596

597

598

599

600

601

602

603

604

605

606

607

608

609

610
(19) Afkar, E.; Lisak, J.; Saltikov, C.; Basu, P.; Oremland, R. S.; Stolz, J. F. The respiratory arsenate reductase from Bacillus selenitireducens strain MLS10. FEMS Microbiol. Lett. 2003, 226 (1), 107-112; DOI 10.1016/S0378-1097(03)00609-8

(20) Mukhopadhyay, R.; Rosen, B. P. Arsenate reductases in prokaryotes and eukaryotes. Environ. Health Perspect. 2002, 110, 745-748; DOI 10.1289/ehp.02110s5745

(21) Bhattacharjee, H.; Sheng, J.; Ajees, A. A.; Mukhopadhyay, R.; Rosen, B. P. Adventitious arsenate reductase activity of the catalytic domain of the human Cdc25B and Cdc25C phosphatases. Biochemistry 2010, 49 (4), 802-809; DOI 10.1021/bi9019127

(22) Zhou, R.; Royyuru, A.; Athma, P.; Suits, F.; Silverman, B. D. Magnitude and spatial orientation of the hydrophobic moments of multi-domain proteins. Int. J. Bioinform. Res. Appl. 2006, 2 (2), 161-176; DOI 10.1016/j.molbiopara.2006.03.009

(23) Chrysostomou, C.; Quandt, E. M.; Marshall, N. M.; Stone, E.; Georgiou, G. An alternate pathway of arsenate resistance in E. coli mediated by the glutathione S-transferase GstB. ACS Chem. Biol. 2015, 10 (3), 875-882; DOI 10.1021/cb500755j

(24) Chao, D. Y.; Chen, Y.; Chen, J.; Shi, S.; Chen, Z.; Wang, C.; Danku, J. M.; Zhao, F. J.; Salt, D. E. Genome-wide Association Mapping Identifies a New Arsenate Reductase Enzyme Critical for Limiting Arsenic Accumulation in Plants. PLoS Biol. 2014, 12 (12); DOI 10.1371/journal.pbio.1002009

(25) Duan, G.-L.; Hu, Y.; Schneider, S.; McDermott, J.; Chen, J.; Sauer, N.; Rosen, B. P.; Daus, B.; Liu, Z.; Zhu, Y.-G. Inositol transporters AtINT2 and AtINT4 regulate arsenic accumulation in Arabidopsis seeds. Nat. Plants 2015, 2 (1), 15202; DOI 10.1038/nplants.2015.202

(26) Duan, G. L.; Zhou, Y.; Tong, Y. P.; Mukhopadhyay, R.; Rosen, B. P.; Zhu, Y. G. A CDC25 homologue from rice functions as an arsenate reductase. New Phytol. 2007, 174 (2), 311-321; DOI 10.1111/j.1469-8137.2007.02009.x

(27) PeipeiWang, Guoxin Sun, Yan Jia, Andrew A Meharg, Y. Z. A review on completing arsenic biogeochemical cycle: Microbial volatilization of arsines in environment. J. Environ. Sci. 2014, 26, 371-381; DOI 10.1016/S1001-0742(13)60432-5

(28) Yin, X.-X.; Chen, J.; Qin, J.; Sun, G.-X.; Rosen, B. P.; Zhu, Y.-G. Biotransformation and volatilization of arsenic by three photosynthetic cyanobacteria. Plant Physiol. 2011, 156 (3), 1631-1638; DOI 10.1104/pp.111.178947

(29) Qin, J.; Rosen, B. P.; Zhang, Y.; Wang, G.; Franke, S.; Rensing, C. Arsenic detoxification and evolution of trimethylarsine gas by a microbial arsenite S-adenosylmethionine methyltransferase. Proc. Natl. Acad. Sci. 2006, 103 (7), 2075-2080; DOI 10.1073/pnas.0506836103

(30) Yin, X. X.; Zhang, Y. Y.; Yang, J.; Zhu, Y. G. Rapid biotransformation of arsenic by a model protozoan Tetrahymena thermophila. Environ. Pollut. 2011, 159 (4), 837-840; DOI 10.1016/j.envpol.2010.12.033

(31) David J. Thomas and Barry P. Rosen. Encyclopedia of Metalloproteins; Uversky, V. N., Kretsinger, R. H., Permyakov, Ei. E. a., Eds.; 2013; Vol. 150; DOI 10.1007/978-1-4614-1533-6

(32) Ye, J.; Rensing, C.; Rosen, B. P.; Zhu, Y. G. Arsenic biomethylation by photosynthetic organisms. Trends Plant Sci. 2012, 17 (3), 155-162; DOI 10.1016/j.tplants.2011.12.003

(33) Xue, X.-M.; Ye, J.; Raber, G.; Francesconi, K. A.; Li, G.; Gao, H.; Yan, Y.; Rensing, C.; Zhu, 
Y.-G. Arsenic Methyltransferase is Involved in Arsenosugar Biosynthesis by Providing DMA. Environ. Sci. Technol. 2017; DOI acs.est.6b04952.

(34) Stolz, J. F.; Perera, E.; Kilonzo, B.; Kail, B.; Crable, B.; Fisher, E.; Ranganathan, M.; Wormer, L.; Basu, P. Biotransformation of 3-nitro-4-hydroxybenzene arsonic acid (Roxarsone) and release of inorganic arsenic by clostridium species. Environ. Sci. Technol. 2007, 41 (3), 818-823; DOI 10.1021/es061802i

(35) Lehr, C. R.; Polishchuk, E.; Radoja, U.; Cullen, W. R. Demethylation of methylarsenic species by Mycobacterium neoaurum. Appl. Organomet. Chem. 2003, 17 (11), 831-834; DOI 10.1002/aoc.544

(36) Yoshinaga, M.; Cai, Y.; Rosen, B. P. Demethylation of methylarsonic acid by a microbial community. Environ. Microbiol. 2011, 13 (5), 1205-1215; DOI 10.1111/j.1462-2920.2010.02420.x

(37) Yoshinaga, M.; Rosen, B. P. A C · As lyase for degradation of environmental organoarsenical herbicides and animal husbandry growth promoters. Proc. Natl Acad. Sci. 2014, 111 (21), 7701-7706; DOI 10.1073/pnas.1403057111

(38) Yan, Y.; Ye, J.; Xue, X.-M.; Zhu, Y.-G. Arsenic Demethylation by a C · As Lyase in Cyanobacterium Nostoc sp. PCC 7120. Environ. Sci. Technol. 2015, 49, 14350-14358; DOI 10.1021/acs.est.5b03357

(39) Craig, P. J. organometallic compounds in the environment; 2013; Vol. 53; DOI 10.1017/CBO9781107415324.004

(40) Edmonds, J. S.; Francesconi, K. A. Arseno-sugars from brown kelp (Ecklonia radiata) as intermediates in cycling of arsenic in a marine ecosystem. Nature . 1981, pp 602-604; DOI $10.1038 / 289602 \mathrm{a} 0$

(41) Morita, M. and Shibata, Y. Isolation and identification of arsenolipid from a brown alga,Undaria pinnatifida (Wakame). Chemosphere 1988, 17, 1147-1152; DOI 10.1016/0045-6535(88)90180-4

(42) Garcii'a-Salgado1, S.; Raber, G.; Raml, R.; Magnes, C.; Francesconi, K. A. Arsenosugar phospholipids and arsenic hydrocarbons in two species of brown macroalgae. Environ. Chem. 2012, 9, 63-66; DOI 10.1071/EN11164

(43) Xue, X.-M.; Raber, G.; Foster, S.; Chen, S.-C.; Francesconi, K. A.; Zhu, Y.-G. Biosynthesis of arsenolipids by the cyanobacterium Synechocystis sp. PCC 6803. Environ. Chem. 2014, 11 (5), 506-513; DOI 10.1071/EN14069

(44) Rumpler, A.; Edmonds, J. S.; Katsu, M.; Jensen, K. B.; Goessler, W.; Raber, G.; Gunnlaugsdottir, H.; Francesconi, K. A. Arsenic-containing long-chain fatty acids in cod-liver oil: A result of biosynthetic infidelity? Angew. Chemie - Int. Ed. 2008, 47 (14), 2665-2667; DOI 10.1002/anie.200705405

(45) Raab, A.; Newcombe, C.; Pitton, D.; Ebel, R.; Feldmann, J. Comprehensive analysis of lipophilic arsenic species in a brown alga (Saccharina latissima). Anal. Chem. 2013, 85 (5), 2817-2824; DOI 10.1021/ac303340t

(46) Taleshi, M. S.; Raber, G.; Edmonds, J. S.; Jensen, K. B.; Francesconi, K. A. Arsenolipids in oil from blue whiting Micromesistius poutassou--evidence for arsenic-containing esters. Sci. Rep. 2014, 4, 7492; DOI 10.1038/srep07492

(47) Taleshi, M. S.; Edmonds, J. S.; Goessler, W.; Ruiz-Chancho, M. J.; Raber, G.; Jensen, K. B.; Francesconi, K. A. Arsenic-containing lipids are natural constituents of sashimi tuna. Environ. 
Sci. Technol. 2010, 44 (4), 1478-1483; DOI 10.1021/es9030358

(48) Taleshi, M. S.; Jensen, K. B.; Raber, G.; Edmonds, J. S.; Gunnlaugsdottir, H.; Francesconi, K. A. Arsenic-containing hydrocarbons: natural compounds in oil from the fish capelin, Mallotus villosus. Chem. Commun. 2008, 39 (39), 4706-4707; DOI 10.1039/b808049f

(49) Amayo, K. O.; Raab, A.; Krupp, E. M.; Gunnlaugsdottir, H.; Feldmann, J. Novel identification of arsenolipids using chemical derivatizations in conjunction with RP-HPLC-ICPMS/ESMS. Anal. Chem. 2013, 85 (19), 9321-9327; DOI 10.1021/ac4020935

(50) Viczek, S. A.; Jensen, K. B.; Francesconi, K. A. Arsenic-containing Phosphatidylcholines: a New Group of Arsenolipids Discovered in Herring Caviar. Angew. Chemie Int. Ed. 2016, 55, 5259-5262; DOI 10.1002/anie.201512031

(51) Van Mooy, B. a S.; Fredricks, H. F.; Pedler, B. E.; Dyhrman, S. T.; Karl, D. M.; Koblízek, M.; Lomas, M. W.; Mincer, T. J.; Moore, L. R.; Moutin, T.; et al. Phytoplankton in the ocean use non-phosphorus lipids in response to phosphorus scarcity. Nature 2009, 458, 69-72; DOI 10.1038/nature07659

(52) Petursdottir, A. H.; Fletcher, K.; Gunnlaugsdottir, H.; Krupp, E.; Kupper, F. C.; Feldmann, J. Environmental effects on arsenosugars and arsenolipids in Ectocarpus (Phaeophyta). Environ. Chem. 2016, 13 (1), 21-33; DOI 10.1071/EN14229

(53) Meyer, S.; Matissek, M.; Müller, S. M.; Taleshi, M. S.; Ebert, F.; Francesconi, K. A.; Schwerdtle, T. In vitro toxicological characterisation of three arsenic-containing hydrocarbons. Metallomics 2014, 6, 1023-1033; DOI 10.1039/c4mt00061g

(54) Schmeisser, E.; Goessler, W.; Francesconi, K. A. Human metabolism of arsenolipids present in cod liver. Anal. Bioanal. Chem. 2006, 385 (2), 367-376; DOI 10.1007/s00216-006-0401-x

(55) Taylor, V.; Goodale, B.; Raab, A.; Schwerdtle, T.; Reimer, K.; Conklin, S.; Karagas, M. R.; Francesconi, K. A. Human exposure to organic arsenic species from seafood. Sci. Total Environ. 2016; DOI 10.1016/j.scitotenv.2016.12.113

(56) Tamaki, S.; Frankenberger, W. T. J. Environmental biochemistry of arsenic. Rev. Environ. Contam. Toxicol. 1992, 124, 79-110; DOI 10.1007/978-1-4612-2864-6_4

(57) Ali, W.; Isayenkov, S. V.; Zhao, F. J.; Maathuis, F. J. M. Arsenite transport in plants. Cell. Mol. Life Sci. 2009, 66 (14), 2329-2339; DOI 10.1007/s00018-009-0021-7

(58) Broer, S.; Ji, G.; Broer, A.; Silver, S. Arsenic efflux governed by the arsenic resistance determinant of Staphylococcus aureus plasmid pI258. J. Bacteriol. 1993, 175 (11), 3480-3485; DOI 10.1128/jb.175.11.3480-3485.1993

(59) Lin, Y.F., Walmsley, A.R. and Rosen, B. An arsenic metallochaperone for an arsenic detoxification pump. Proc. Natl. Acad. Sci. 2006, 103, 15617-15622; DOI 10.1073?pnas.0603974103

(60) Yang, H.; Cheng, J.; Finan, T. M.; Rosen, B. P. Novel Pathway for Arsenic Detoxification in the Legume Symbiont Sinorhizobium meliloti. J. Bacteriol. 2005, 187 (20), 6991-6997; DOI 10.1128/JB.187.20.6991

(61) Wysocki, R.; Goffeau, A. Isolation of Three Contiguous Genes, ACR1, ACR2 and ACR3, Involved in Resistance to Arsenic Compounds in the Yeast Saccharomyces cerevisiae. Yeast 1997, 13, 819-828; DOI 10.1002/(SICI)1097-0061(199707)13

(62) Ghosh, M.; Shen, J.; Rosen, B. P. Pathways of As ( III ) detoxification in Saccharomyces cerevisiae. Proc. Natl Acad. Sci. 1999, 96, 5001-5006; DOI 10.1073/pnas.96.9.5001

(63) Chen, J.; Yoshinaga, M.; Garbinski, L. D.; Rosen, B. P. Synergistic interaction of 
glyceraldehydes-3-phosphate dehydrogenase and ArsJ, a novel organoarsenical efflux permease, confers arsenate resistance. Mol. Microbiol. 2016, 100 (6), 945-953; DOI 10.1111/mmi.13371

(64) Chen, J.; Madegowda, M.; Bhattacharjee, H.; Rosen, B. P. ArsP: A methylarsenite efflux permease. Mol. Microbiol. 2015, 98 (4), 625-635; DOI 10.1111/mmi.13145

(65) Li, J.; Pawitwar, S. S.; Rosen, B. P. The organoarsenical biocycle and the primordial antibiotic methylarsenite. Metallomics 2016, 8, 1047-1055; DOI 10.1039/C6MT00168H

(66) Chen, X.-P.; Zhu, Y.-G.; Hong, M.-N.; Kappler, A.; Xu, Y.-X. Effects of different forms of nitrogen fertilizers on arsenic uptake by rice plants. Environ. Toxicol. Chem. 2008, 27 (4), 881-887; DOI 10.1897/07-368.1

(67) Carlson, H. K.; Clark, I. C.; Blazewicz, S. J.; Iavarone, A. T.; Coates, J. D. Fe(II) oxidation is an innate capability of nitrate-reducing bacteria that involves abiotic and biotic reactions. $J$. Bacteriol. 2013, 195 (14), 3260-3268; DOI 10.1128/JB.00058-13

(68) Bertin, P. N.; Heinrich-Salmeron, A.; Pelletier, E.; Goulhen-Chollet, F.; Arsène-Ploetze, F.; Gallien, S.; Lauga, B.; Casiot, C.; Calteau, A.; Vallenet, D.; et al. Metabolic diversity among main microorganisms inside an arsenic-rich ecosystem revealed by meta- and proteo-genomics. ISME J. 2011, 5 (11), 1735-1747; DOI 10.1038/ismej.2011.51

(69) Melton, E. D.; Swanner, E. D.; Behrens, S.; Schmidt, C.; Kappler, A. The interplay of microbially mediated and abiotic reactions in the biogeochemical Fe cycle. Nat. Rev. Microbiol. 2014, 12 (12), 797-809; DOI 10.1038/nrmicro3347

(70) Masscheleyn, P. H.; Delaune, R. D.; Patrick, Jr., W. H. Effect of Redox Potential and pH on Arsenic Speciation and Solubility in a Contaminated Soil. Environ. Sci. Technol. 1991, 25 (8), 1414-1419; DOI 10.1021/es00020a008

(71) Dixit, S.; Hering, J. G. Comparison of arsenic(V) and arsenic(III) sorption onto iron oxide minerals: Implications for arsenic mobility. Environ. Sci. Technol. 2003, 37 (18), 4182-4189; DOI $10.1021 / \mathrm{es} 030309 \mathrm{t}$

(72) Amstaetter, K.; Borch, T.; Larese-Casanova, P.; Kappler, A. Redox transformation of arsenic by Fe(II)-activated goethite (-FeOOH). Environ. Sci. Technol. 2010, 44 (1), 102-108; DOI $10.1021 / \mathrm{es} 901274 \mathrm{~s}$

(73) Borch, T.; Kretzschmar, R.; Kappler, A.; Van Cappellen, P.; Ginder-Vogel, M.; Voegelin, A.; Campbell, K. Biogeochemical redox processes and their impact on contaminant dynamics. Environ. Sci. Technol. 2010, 44 (1), 15-23; DOI 10.1021/es9026248

(74) Liu, W. J.; Zhu, Y. G.; Smith, F. A.; Smith, S. E. Do iron plaque and genotypes affect arsenate uptake and translocation by rice seedlings (Oryza sativa L.) grown in solution culture? J. Exp. Bot. 2004, 55 (403), 1707-1713; DOI 10.1093/jxb/erh205

(75) Liu, W. J.; Zhu, Y. G.; Hu, Y.; Williams, P. N.; Gault, A. G.; Meharg, A. A.; Charnock, J. M.; Smith, F. A. Arsenic sequestration in iron plaque, its accumulation and speciation in mature rice plants (Oryza Sativa L.). Environ. Sci. Technol. 2006, 40 (18), 5730-5736; DOI $10.1021 / \mathrm{es} 060800 \mathrm{v}$

(76) Chen, Z.; Zhu, Y. G.; Liu, W. J.; Meharg, A. A. Direct evidence showing the effect of root surface iron plaque on arsenite and aresnate uptake in rice (Oryza sativa) roots. New Phytol. 2005, 165 (1), 91-97; DOI 10.1111/j.1469-8137.2004.01241.x

(77) Cummings, D. E.; Caccavo, F.; Fendorf, S.; Rosenzweig, R. F. Arsenic mobilization by the dissimilatory Fe(III)-reducing bacterium Shewanella alga BrY. Environ. Sci. Technol. 1999, 33 
(78) Wang, X.-J.; Chen, X.-P.; Kappler, A.; Sun, G.-X.; Zhu, Y.-G. Arsenic binding to iron (II) minerals produced by an iron (III)-reducing aeromonas strain isolated from paddy soil. Environ. Toxicol. Chem. 2009, 28 (11), 2255-2262; DOI 10.1897/09-085.1

(79) Muehe, E. M.; Scheer, L.; Daus, B.; Kappler, A. Fate of arsenic during microbial reduction of biogenic versus abiogenic As-Fe(III)-mineral coprecipitates. Environ. Sci. Technol. 2013, 47 (15), 8297-8307; DOI 10.1021/es400801z

(80) Muehe, E. M.; Morin, G.; Scheer, L.; Le Pape, P.; Esteve, I.; Daus, B.; Kappler, A. Arsenic(V) Incorporation in Vivianite during Microbial Reduction of Arsenic(V)-Bearing Biogenic Fe(III) (Oxyhydr)oxides. Environ. Sci. Technol. 2016, 50 (5), 2281-2291; DOI10.1021/acs.est.5b04625

(81) Wang, X.; Chen, X.; Yang, J.; Wang, Z.; Sun, G. Effect of microbial mediated iron plaque reduction on arsenic mobility in paddy soil. J. Environ. Sci. 2009, 21 (11), 1562-1568; DOI 10.1016/S1001-0742(08)62456-0

(82) Islam, F. S.; Gault, A. G.; Boothman, C.; Polya, D. a; Charnock, J. M.; Chatterjee, D.; Lloyd, J. R. Role of metal-reducing bacteria in arsenic release from Bengal delta sediments. Nature 2004, 430 (6995), 68-71; DOI 10.1038/nature02638

(83) Campbell, K. M.; Malasarn, D. Simultaneous Microbial Reduction of Iron ( III ) and Arsenic ( V ) in Suspensions of Hydrous Ferric Oxide. Env. Sci Technol 2006, 40 (19), 5950-5955; DOI 10.1021/es0600476

(84) Kocar, B. D.; Herbel, M. J.; Tufano, K. J.; Fendorf, S. Contrasting effects of dissimilatory iron (III) and arsenic (V) reduction on arsenic retention and transport. Environ. Sci. Technol. 2006, 40 (21), 6715-6721; DOI 10.1021/es061540k

(85) Stolz, R. S. O. and J. F. Arsenic, microbes and contaminated aquifers. Trends Microbiol. 2005, 13 (2), 45-49; DOI 10.1155/2011/863623

(86) Rochette, E. A.; Bostick, B. C.; Li, G.; Fendorf, S. Kinetics of arsenate reduction by dissolved sulfide. Environ. Sci. Technol. 2000, 34 (22), 4714-4720; DOI 10.1021/es000963y

(87) Newman, D. K.; Kennedy, E. K.; Coates, J. D.; Ahmann, D.; Ellis, D. J.; Lovley, D. R.; Morel, F. M. M. Dissimilatory arsenate and sulfate reduction in Desulfotomaculum auripigmentum sp. nov. Arch. Microbiol. 1997, 168 (5), 380-388; DOI 10.1007/s002030050512

(88) Rittle, K. A.; Drever, J. I.; Colberg, P. J. S. Precipitation of Arsenic during Bacterial Sulfate Reduction. Geomicrobiol. J. 1995, 13 (1), 1-11; DOI 10.1080/01490459509378000

(89) Hohmann, C.; Winkler, E.; Morin, G.; Kappler, A. Anaerobic Fe(II)-oxidizing bacteria show as resistance and immobilize as during Fe(III) mineral precipitation. Environ. Sci. Technol. 2010, 44 (1), 94-101; DOI 10.1021/es900708s

(90) Hohmann, C.; Morin, G.; Ona-Nguema, G.; Guigner, J. M.; Brown, G. E.; Kappler, A. Molecular-level modes of As binding to $\mathrm{Fe}(\mathrm{III})$ (oxyhydr)oxides precipitated by the anaerobic nitrate-reducing Fe(II)-oxidizing Acidovorax sp. strain BoFeN1. Geochim. Cosmochim. Acta 2011, 75 (17), 4699-4712; DOI 10.1016/j.gca.2011.02.044

1) Nitzsche, K. S.; Weigold, P.; Lösekann-Behrens, T.; Kappler, A.; Behrens, S. Microbial community composition of a household sand filter used for arsenic, iron, and manganese removal from groundwater in Vietnam. Chemosphere 2015, 138, 47-59; DOI 10.1016/j.chemosphere.2015.05.032

(92) Kleinert, S.; Muehe, E. M.; Posth, N. R.; Dippon, U.; Daus, B.; Kappler, A. Biogenic Fe(III) 
minerals lower the efficiency of iron-mineral-based commercial filter systems for arsenic removal. Environ. Sci. Technol. 2011, 45 (17), 7533-7541; DOI 10.1021/es201522n

(93) Hoeft, S. E.; Blum, J. S.; Stolz, J. F.; Tabita, F. R.; Witte, B.; King, G. M.; Santini, J. M.; Oremland, R. S. Alkalilimnicola ehrlichii sp. nov., a novel, arsenite-oxidizing haloalkaliphilic

(94) Rhine, E. D.; Phelps, C. D.; Young, L. Y. Anaerobic arsenite oxidation by novel denitrifying 795

(96) Senko, J. M.; Dewers, T. A.; Krumholz, L. R. Effect of Oxidation Rate and Fe (II) State on Microbial Nitrate-Dependent Fe (III) Mineral Formation. Appl. Environ. Microbiol. 2005, 71 (11), 7172-7177; DOI 10.1128/AEM.71.11.7172

(97) Weber, K. A.; Urrutia, M. M.; Churchill, P. F.; Kukkadapu, R. K.; Roden, E. E. Anaerobic redox cycling of iron by freshwater sediment microorganisms. Environ. Microbiol. 2006, 8, 100-113; DOI 10.1111/j.1462-2920.2005.00873.x

(98) Schippers, A.; Jorgensen, B. B. Biogeochemistry of pyrite and iron sulfide oxidation in marine sediments. Geochim. Cosmochim. Acta 2002, 66 (1), 85-92; DOI 10.1016/S0016-7037(01)00745-1

(99) Jiang, J.; Bauer, I.; Paul, A.; Kappler, A. Arsenic redox changes by microbially and chemically formed semiquinone radicals and hydroquinones in a humic substance model quinone. Environ. Sci. Technol. 2009, 43 (10), 3639-3645; DOI 10.1021/es803112a

(100) Sharma, P.; Rolle, M.; Kocar, B. D.; Fendorf, S.; Kapppler, A. Influence of Natural Organic Matter on As Transport and Retention. Environ. Sci. Technol. 2010, 45 (2), 546-553; DOI 10.2134/jeq2003.1393

(101) Sharma, P.; Kappler, A. Desorption of arsenic from clay and humic acid-coated clay by dissolved phosphate and silicate. J. Contam. Hydrol. 2011, 126 (3-4), 216-225; DOI 10.1016/j.jconhyd.2011.08.005

(102) Bauer, M.; Blodau, C. Arsenic distribution in the dissolved, colloidal and particulate size fraction of experimental solutions rich in dissolved organic matter and ferric iron. Geochim. Cosmochim. Acta 2009, 73 (3), 529-542; DOI 10.1016/j.gca.2008.10.030

(103) Peatland, A.; Thomasarrigo, L. K.; Mikutta, C.; Byrne, J.; Barmettler, K.; Kappler, A.; Kretzschmar, R. Iron and Arsenic Speciation and Distribution in Organic Flocs from Streambeds of an Arsenic-Enriched Peatland. Environ. Sci. Technol. 2014, No. 48, 13218-13228; DOI 10.1021/es503550g

(104) Buschmann, J.; Kappeler, A.; Lindauer, U.; Kistler, D.; Berg, M.; Sigg, L. Arsenite and arsenate binding to dissolved humic acids: Influence of $\mathrm{pH}$, type of humic acid, and aluminum. Environ. Sci. Technol. 2006, 40 (19), 6015-6020; DOI 10.1021/es061057+

(105) Redman, A. D.; Macalady, D.; Ahmann, D. Natural organic matter affects arsenic speciation and sorption onto hematite. Environ. Sci. Technol. 2002, 36 (13), 2889-2896; DOI $10.1021 / \mathrm{es} 0112801$ 
(106) Sharma, P.; Ofner, J.; Kappler, A. Formation of binary and ternary colloids and dissolved complexes of organic matter, Fe and As. Environ. Sci. Technol. 2010, 44 (12), 4479-4485; DOI $10.1021 / \mathrm{es} 100066 \mathrm{~s}$

(107) Langner, P.; Mikutta, C.; Kretzschmar, R. Arsenic sequestration by organic sulphur in peat. Nat. Geosci. 2011, 5 (1), 66-73; DOI 10.1038/ngeo1329

(108) Huang, H.; Jia, Y.; Sun, G.-X.; Zhu, Y.-G. Arsenic speciation and volatilization from flooded paddy soils amended with different organic matters-supporting information. Environ. Sci. Technol. 2012, 46 (4), 2163-2168; DOI 10.1021/es203635s

(109) Jia, Y.; Huang, H.; Chen, Z.; Zhu, Y. G. Arsenic uptake by rice is influenced by microbe-mediated arsenic redox changes in the rhizosphere. Environ. Sci. Technol. 2014, 48 (2), 1001-1007; DOI 10.1021/es403877s

(110) Liu, W. J.; McGrath, S. P.; Zhao, F. J. Silicon has opposite effects on the accumulation of inorganic and methylated arsenic species in rice. Plant Soil 2014, 376 (1-2), 423-431; DOI 10.1007/s11104-013-1991-7

(111) Zhang, S.; Williams, P. N.; Luo, J.; Zhu, Y. Microbial mediated arsenic biotransformation in wetlands. Front. Environ. Sci. eng. 2017, 11 (1), 1-11; DOI 10.1007/s11783-017-0893-y

(112) Zhang, S. Y.; Zhao, F. J.; Sun, G. X.; Su, J. Q.; Yang, X. R.; Li, H.; Zhu, Y. G. Diversity and abundance of arsenic biotransformation genes in paddy soils from southern china. Environ. Sci. Technol. 2015, 49 (7), 4138-4146; DOI 10.1021/acs.est.5b00028

(113) Jia, Y.; Huang, H.; Sun, G. X.; Zhao, F. J.; Zhu, Y. G. Pathways and relative contributions to arsenic volatilization from rice plants and paddy soil. Environ. Sci. Technol. 2012, 46 (15), 8090-8096; DOI 10.1021/es300499a

(114) Meharg, A. A.; Williams, P. N.; Adomako, E.; Lawgali, Y. Y.; Deacon, C.; Villada, A.; Cambell, R. C. J.; Sun, G.; Zhu, Y. G.; Feldmann, J.; et al. Geographical variation in total and inorganic arsenic content of polished (white) rice. Environ. Sci. Technol. 2009, 43 (5), 1612-1617; DOI 10.1021/es802612a

(115) Sun, G. X.; Williams, P. N.; Carey, A. M.; Zhu, Y. G.; Deacon, C.; Raab, A.; Feldmann, J.; Islam, R. M.; Meharg, A. A. Inorganic arsenic in rice bran and its products are an order of magnitude higher than in bulk grain. Environ. Sci. Technol. 2008, 42 (19), 7542-7546; DOI $10.1021 / \mathrm{es} 801238 \mathrm{p}$

(116) Sun, G. X.; Williams, P. N.; Zhu, Y. G.; Deacon, C.; Carey, A. M.; Raab, A.; Feldmann, J.; Meharg, A. A. Survey of arsenic and its speciation in rice products such as breakfast cereals, rice crackers and Japanese rice condiments. Environ. Int. 2009, 35 (3), 473-475; DOI 10.1016/j.envint.2008.07.020

(117) Lomax, C.; Liu, W. J.; Wu, L.; Xue, K.; Xiong, J.; Zhou, J.; McGrath, S. P.; Meharg, A. A.; Miller, A. J.; Zhao, F. J. Methylated arsenic species in plants originate from soil microorganisms. New Phytol. 2012, 193 (3), 665-672; DOI 10.1111/j.1469-8137.2011.03956.x

(118) Chauhan, N. S.; Ranjan, R.; Purohit, H. J.; Kalia, V. C.; Sharma, R. Identifcation of genes conferring arsenic resistance to Escherichia coli from an effluent treatment plant sludge metagenomic library. FEMS Microbiol Ecol 2009, 67, 130-139; DOI 10.1111/j.1574-6941.2008.00613.x

(119) Xiao, K. Q.; Li, L. G.; Ma, L. P.; Zhang, S. Y.; Bao, P.; Zhang, T.; Zhu, Y. G. Metagenomic analysis revealed highly diverse microbial arsenic metabolism genes in paddy soils with low-arsenic contents. Environ. Pollut. 2016, 211, 1-8; DOI 10.1016/j.envpol.2015.12.023 
(120) Lu, K.; Mahbub, R.; Cable, P. H.; Ru, H.; Parry, N. M. A.; Bodnar, W. M.; Wishnok, J. S.; Styblo, M.; Swenberg, J. A.; Fox, J. G.; et al. Gut Microbiome Phenotypes Driven by Host Genetics Affect Arsenic Metabolism. Chem. Res. Toxicol. 2014, 27, 172-174; DOI $/ 10.1021 / \mathrm{tx} 400454 \mathrm{z}$

(121) Cai, L.; Yu, K.; Yang, Y.; Chen, B. W.; Li, X. D.; Zhang, T. Metagenomic exploration reveals high levels of microbial arsenic metabolism genes in activated sludge and coastal sediments. Appl. Microbiol. Biotechnol. 2013, 97 (21), 9579-9588; DOI 10.1007/s00253-012-4678-8

(122) Aguiar-pulido, V.; Huang, W.; Suarez-ulloa, V.; Cickovski, T.; Mathee, K.; Narasimhan, G. Metagenomics, Metatranscriptomics, and Metabolomics Approaches for Microbiome Analysis. Evol. Bioinforma. 2016, 12 (S1), 5-16; DOI 10.4137/EBO.S36436.TYPE

(123) Mary Ann Moran. Metatranscriptomics: Eavesdropping on Complex Microbial Communities-Large-scale sequencing of mRNAs retrieved from natural communities provides insights into microbial activities and how they are regulated. Microbe 2009, 4 (7), 329.

(124) Manpreet, K. Isolation and Characterization of Metal Resistance Genes by using Metatranscriptomic Approach, Thapar institute of engineering and technolgy university, 2014.

(125) Carvalhais, L. C.; Dennis, P. G.; Tyson, G. W.; Schenk, P. M. Application of metatranscriptomics to soil environments. J. Microbiol. Methods 2012, 91 (2), 246-251; DOI 10.1016/j.mimet.2012.08.011

(126) Gilbert, J. A.; Field, D.; Huang, Y.; Edwards, R.; Li, W.; Gilna, P.; Joint, I. Detection of Large Numbers of Novel Sequences in the Metatranscriptomes of Complex Marine Microbial Communities. PLoS One 2008, 3 (8); DOI 10.1371/journal.pone.0003042

(127) Lafuente, A.; Patricia, P.; Molina-s, D.; Caviedes, M. A.; Rodr, I. D. Unraveling the effect of arsenic on the model Medicago - Ensifer interaction : a transcriptomic meta-analysis. The ISME journal 2015, 205, 255-272; DOI 10.1111/nph.13009

(128) Zhang, Y.; Chen, S.; Hao, X.; Su, J. Q.; Xue, X.; Yan, Y.; Zhu, Y. G.; Ye, J. Transcriptomic analysis reveals adaptive responses of an enterobacteriaceae strain LSJC7 to arsenic exposure. Front. Microbiol. 2016, 7, 1-12; DOI 10.3389/fmicb.2016.00636

(129) VerBerkmoes, N. C.; Denef, V. J.; Hettich, R. L.; Banfield, J. F. Functional analysis of natural microbial consortia using community proteomics. Nat Rev Microbiol 2009, 7 (3), 196-205; DOI 10.1038/nrmicro2080

(130) Fiehn, O. Metabolomics - The link between genotypes and phenotypes. Plant Mol. Biol. 2002, 48 (1-2), 155-171; DOI 10.1023/A:1013713905833

(131) Schneider, T.; Riedel, K. Environmental proteomics: Analysis of structure and function of microbial communities. Proteomics 2010, 10 (4), 785-798; DOI 10.1002/pmic.200900450

(132) Lankadurai, B. P.; Nagato, E. G.; Simpson, M. J. Environmental metabolomics : an emerging approach to study organism responses to environmental stressors. Environ. Rev. 2013, 21, 180-205; DOI 10.1139/er-2013-0011

(133) Halter, D.; Cordi, A.; Gribaldo, S.; Gallien, S.; Goulhen-Chollet, F.; Heinrich-Salmeron, A.; Carapito, C.; Pagnout, C.; Montaut, D.; Seby, F.; et al. Taxonomic and functional prokaryote diversity in mildly arsenic-contaminated sediments. Res. Microbiol. 2011, 162 (9), 878-887; DOI 10.1016/j.resmic.2011.06.001

(134) Shi, X.; Wei, X.; Koo, I.; Schmidt, R. H.; Yin, X.; Kim, S. H.; Vaughn, A.; Mcclain, C. J.; Arteel, G. E.; Zhang, X.; et al. Metabolomic Analysis of the E ff ects of Chronic Arsenic Exposure in a Mouse Model of Diet-Induced Fatty Liver Disease. J. Proteome Res. 2014, 13, 

elemental metabolisms. 10.1039/c3ra40897c

\section{Legends}

\section{Associated content}

547-554; DOI 10.1021/pr400719u

(135) Bastida, F.; Moreno, J. L.; Nicolás, C.; Hernández, T.; García, C. Soil metaproteomics: A review of an emerging environmental science. Significance, methodology and perspectives. Eur. J. Soil Sci. 2009, 60 (6), 845-859; DOI 10.1111/j.1365-2389.2009.01184.x

(136) Lu, K.; Abo, R. P.; Schlieper, K. A.; Michelle, E.; Levine, S.; Wishnok, J. S.; Swenberg, J. A.; Tannenbaum, S. R.; Fox, J. G. Arsenic Exposure Perturbs the Gut Microbiome and Its Metabolic Profile in Mice : An Integrated Metagenomics and Metabolomics Analysis. Environ. Health Perspect. 2014, 122, 284-291; DOI 10.1289/ehp.1307429

(137) Tripathi, R. D.; Tripathi, P.; Dwivedi, S.; Dubey, S.; Chatterjee, S.; Chakrabarty, D.; Trivedi, P. K. Arsenomics: Omics of arsenic metabolism in plants. Front. Physiol. 2012, 3, 1-14; DOI 10.3389/fphys.2012.00275

(138) Sacheti, P.; Bhonsle, H.; Patil, R.; Kulkarni, M. J.; Srikanth, R.; Gade, W. Arsenomics of Exiguobacterium sp. PS (NCIM 5463). RSC Adv. 2013, 3, 9705-9713; DOI

(139) Reed, D. C.; Algar, C. K.; Huber, J. A.; Dick, G. J. Gene-centric approach to integrating environmental genomics and biogeochemical models. Proc. Natl Acad. Sci. 2014, 111 (5), 1879-1884; DOI 10.1073/pnas.1313713111

(140) Louca, S.; Hawley, A. K.; Katsev, S.; Torres-Beltran, M.; Bhatia, M. P.; Kheirandish, S.; Michiels, C. C.; Capelle, D.; Lavik, G.; Doebeli, M.; et al. Integrating biogeochemistry with multiomic sequence information in a model oxygen minimum zone. Proc. Natl. Acad. Sci. 2016, 113 (40), E5925-E5933; DOI 10.1073/pnas.1602897113

Fig. 1. Pathways for arsenic redox reactions and synthesis of novel organoarsenicals.

Fig. 2. The model of effect of Fe, N, S and natural organic matter (NOM) on arsenic biogeochemical cycling highlights proteins encoded by genes associated with

950 Supporting Information: The genes involved in arsenic metabolisms (Table S1). 